Original Research Paper

\title{
PENGARUH METODE MASERASI DAN SOKLETASI TERHADAP STABILITAS FISIK SEDIAAN HAIR TONIC EKSTRAK ETANOL DAUN LIDAH MERTUA
} (Sansevieria trifasciata P.)

Gina Septiani Agustien*, Susanti

Program Studi Farmasi, Universitas Perjuangan

Email Corresponding: ginaagustien@gmail.com

Page : $30-37$

Kata Kunci : Hair Tonic, Daun Lidah Mertua, Maserasi, Sokletasi, Stabilitas Fisik

Keywords: Hair Tonic, Sansevieria Leaves, Maceration, Soxhletation, Physical Stability.

Published by:

Tadulako University,

Managed by Faculty of Medicine.

Email: healthytadulako@gmail.com

Phone (WA): +6285242303103

Address:

Jalan Soekarno Hatta Km. 9. City of

Palu, Central Sulawesi, Indonesia
Rambut rontok adalah kelainan dimana jumlah rambut berkurang atau rontok lebih dari biasanya tanpa penipisan yang terlihat. Perawatan rambut membutuhkan berbagai produk kosmetik seperti kondisioner rambut, creambath dan hair tonic. Hair tonic memiliki beberapa keuntungan dalam mengoptimalkan upaya pencegahan kerontokan dibandingkan perawatan rambut lainnya. Lidah mertua (Sansevieria trifasciata) merupakan tanaman yang dikenal sebagai tanaman hias. Hampir semua bagian tanaman lidah mertua dapat dimanfaatkan, namun belum banyak yang tahu bahwa daun lidah mertua bisa dimanfaatkan sebagai hair tonic untuk mengatasi rambut rontok. Tujuan penelitian ini untuk mengetahui pengaruh metode maserasi dan sokletasi terhadap stabilitas fisik sediaan hair tonic ekstrak daun lidah mertua dengan variasi konsentrasi 1\%, 3\% dan 6\%. Evaluasi sediaan meliputi uji organoleptik, $\mathrm{pH}$, bobot jenis dan viskositas. Uji stabilitas fisik dilakukan pada suhu rendah $\left(4^{\circ} \mathrm{C}\right)$ dan suhu tinggi $\left(40^{\circ} \mathrm{C}\right)$. Hasil uji menunjukan $(p$-value $<0.05)$ tidak ada pengaruh antara metode maserasi dan sokletasi terhadap stabilitas fisik sediaan hair tonic ekstrak lidah mertua

\section{ABSTRACT}

Hair loss is a disorder in which the amount of hair decreases or falls out more than usual without visible thinning. Hair care requires a variety of cosmetic products such as hair conditioner, cream bath and hair tonic. Hair tonic has several advantages in optimizing efforts to prevent hair loss compared to other hair treatments. Sansevieria leaves (Sansevieria trifasciata) is a plant known as an ornamental plant. Almost all parts of the sansevieria leaves can be used, but not many know that the sansevieria leaves can be used as a hair tonic to treat hair loss. The purpose of this study was to determine the effect of maceration and soxhletation methods on the physical stability of hair tonic preparations of sansevieria leaves extract with varying concentrations of 1\%, 3\% and $6 \%$. Evaluation of the preparation includes organoleptic, $p H$, specific gravity and viscosity tests. Physical stability tests were carried out at low temperatures $\left(4^{\circ} \mathrm{C}\right)$ and high temperatures $\left(40^{\circ} \mathrm{C}\right)$. The test results showed ( $p$-value $\left.<0.05\right)$ there was no effect between maceration and soxhletation methods on the physical stability of the hair tonic preparation of sansevieria leaves extract.

\section{PENDAHULUAN}

Rambut merupakan mahkota wanita yang mencerminkan kepribadian, umur, dan kesehatan. Merawat rambut pada dasarnya sangatlah mudah, diawali dengan membersihkan rambut minimal 2 hari sekali, rambut memiliki peran dalam melindungi dari lingkungan yang merugikan, seperti suhu dingin, panas dan sinar ultraviolet. Selain itu rambut juga berfungsi untuk melindungi kulit dari pengaruh buruk seperti alis untuk melindungi mata agar keringat tidak mengalir ke mata ${ }^{1}$.

Perawatan rambut membutuhkan berbagai produk kosmetik seperti kondisioner rambut, creambath dan hair tonic ${ }^{2}$. Hair tonic memiliki beberapa keuntungan dalam mengoptimalkan upaya pencegahan kerontokan 
dibandingkan perawatan rambut lainnya. Dimana penggunaan hair tonic sangat mudah digunakan, cepat meresap dan tidak terasa lengket pada kulit kepala serta merupakan sediaan yang sudah sering digunakan oleh masyarakat ${ }^{3}$.

Banyak bahan alami yang berasal dari tumbuh-tumbuhan yang dapat digunakan sebagai bahan aktif sediaan hair tonic, bahan alam tersebut berfungsi menyuburkan rambut dan mencegah kerontokan rambut, salah satu bahan alam yang bisa digunakan untuk sediaan hair tonic yaitu lidah mertua. Lidah mertua tergolong tanaman hias yang mengesankan karena memiliki bentuk yang khas dan sistem pemeliharan yang mudah. Hampir semua bagian tanaman lidah mertua dapat dimanfaatkan, namun belum banyak yang tahu bahwa daun lidah mertua bisa dimanfaatkan sebagai hair tonic untuk mengatasi rambut rontok ${ }^{4}$.

Lidah mertua mengandung senyawa sekunder polifenol, glikosida, saponin, tanin, dan flavonoid ${ }^{5}$. Flavonoid termasuk salah satu golongan metabolit sekunder yang dihasilkan oleh tanaman yang termasuk dalam kelompok besar polifenol. Flavonoid mempunyai kemampuan sebagai penangkal radikal bebas dan menghambat oksidasi lipid dan telah digunakan untuk suplemen kesehatan ${ }^{6}$.

Hair tonic merupakan sediaan kosmetik berbentuk cair, merupakan campuran bahan kimia atau bahan lainnya yang digunakan untuk membantu memperkuat, meningkatkan pertumbuhan dan menjaga kondisi rambut. Fungsi dari hair tonic yaitu untuk memperlancar peredaran darah pada kulit kepala sehingga dapat mencegah rambut rontok, meningkatkan pertumbuhan rambut, mencegah timbulnya ketombe dan gatal serta memberikan rasa segar pada kulit kepala ${ }^{7}$.

Maserasi dengan cara penyarian yang sederhana, yang dilakukan dengan cara merendam serbuk simplisia dalam cairan penyari. Cairan penyari akan menembus dinding sel dan masuk kedalam rongga sel yang mengandung zat aktif. Sedangkan sokletasi merupakan metode cara panas yang dapat menghasilkan ekstrak yang tersari lebih banyak, pelarut yang digunakan lebih sedikit, namun metode cara panas ini tidak dapat digunakan untuk komponen-komponen kimia yang tidak tahan panas ${ }^{8}$.

Tujuan penelitian adalah untuk mengetahui pengaruh metode ekstraksi dan sokletasi terhadap stabilitas fisik sediaan hair tonik ekstrak daun lidah mertua. Manfaat penelitian yaitu memberikan tambahan pengetahuan dan menjelaskan bukti empiris pengaruh metode ekstraksi dan sokletasi terhadap stabilitas fisik sediaan hair tonik ekstrak daun lidah mertua.

\section{METODE PENELITIAN}

Alat

Alat yang digunakan pada penelitian ini adalah Neraca digital (Fujitsu®), Oven (Memmert), Blender (Philips), Rotary Evaporator (Buchi®), pH Meter (lutron pH201), Water bath (B-One), Hot Plate, Viskometer Ostwald (Cannon), Piknometer (Pyrex).

\section{Bahan}

Bahan yang digunakan pada penelitian ini adalah daun lidah mertua (Sansevieria trifasciata P.), Etanol 96\%, Propilen Glikol, Tween 80, Methyl Paraben, $\mathrm{Na}_{2}$ EDTA, Menthol, Sodium Metabisulfit, Aquadest.

\section{Pengumpulan dan Penyiapan Simplisia}

Daun lidah mertua diperoleh dari daerah Kabupaten Tasikmalaya, Jawa Barat. Determinasi tanaman dilakukan di Program Studi Biologi, Fakultas Keguruan Dan Ilmu Pendidikan Universitas Galuh.

Simplisia yang telah didapatkan di sortasi basah, kemudian dicuci menggunakan air mengalir, ditiriskan kemudian dirajang. Simplisia yang telah dilakukan perajangan kemudian dikeringkan dalam oven dan 
dilakukan sortasi kering. Simplisia yang telah kering kemudian di serbuk sampai halus dengan menggunakan ayakan mesh $60^{9}$.

\section{Proses Ekstraksi Maeserasi}

Metode maserasi daun lidah mertua menggunakan pelarut etanol $96 \%$ sampai serbuk tersebut terendam dengan ketinggian pelarut $3 \mathrm{~cm}$ diatas serbuk, sesekali dilakukan pengadukan pada campuran tersebut dan didiamkan lebih kurang selama satu hari atau 24 jam. Campuran kemudian disaring untuk memperoleh filtrat dan memisahkannya dari ampas. Ampas yang diperoleh dilakukan maserasi lagi selama 3 kali untuk memastikan bahwa senyawa-senyawa yang terkandung dalam simplisia telah tersari dengan sempurna.
Setelah itu dilakukan rotary evaporator pada suhu $70^{\circ} \mathrm{C}$ hingga didapatkan ekstrak kental ${ }^{10}$.

\section{Proses Ekstraksi Sokletasi}

Serbuk simplisia dibungkus dengan kertas saring diikat kedua bagian ujungnya dengan benang masukan kedalam alat sokletasi masukan pelarut etanol 96\% ke dalam labu alas bulat untuk membasahi sampel, dengan suhu $70^{\circ} \mathrm{C}$ sampai tetesan tidak berwarna lagi. Filtrat yang diproleh dilakukan pemekatan dengan rotary evaporator hingga menjadi ekstrak kental. Kemudian dihitung rendemennya ${ }^{10}$.

\section{Formulasi Hair tonic}

Formula hair tonik ekstrak etanol daun lidah mertua dapat dilihat pada tabel 1

Tabel 1. Formula Hair Tonic Ekstrak Daun Lidah Mertua

\begin{tabular}{llllll}
\hline \multirow{2}{*}{ No } & \multirow{2}{*}{ Bahan } & Kontrol (-) & FI & FII & FIII \\
\cline { 3 - 6 } & & \multicolumn{5}{c}{$(\%)$} \\
\hline 1. & Ekstrak lidah mertua & - & 1 & 3 & 6 \\
2. & Etanol 96\% & 30 & 30 & 30 & 30 \\
3. & Propilen glikol & 15 & 15 & 15 & 15 \\
4. & Tween 80 & 1 & 1 & 1 & 1 \\
5. & Methyl paraben & 0.075 & 0.075 & 0.075 & 0.075 \\
6. & Na2EDTA & 0.025 & 0.025 & 0.025 & 0.025 \\
7. & Menthol & 0.100 & 0.100 & 0.100 & 0.100 \\
8. & Sodium metabisulfit & 0.200 & 0.200 & 0.200 & 0.200 \\
9. & Aquadest & Add 100 & Add 100 & Add 100 & Add 100 \\
\hline
\end{tabular}

Pembuatan sediaan hair tonic dilakukan beberapa tahap yaitu, melarutkan tween 80 dalam etanol hingga larut, kemudian tambahkan ekstrak aduk hingga larut sempurna. Sodium metabisulfit dan dinatrium EDTA dilarutkan dalam aquades hingga larut. Larutan dicampurkan aduk hingga homogen. Dilarutkan masing-masing metil paraben dan menthol dalam etanol hingga larut. Kemudian mencampurkan keduanya, aduk homogen lalu ditambahkan propilenglikol aduk hingga homogen. Selanjutnya ditambahkan aquades sampai $100 \mathrm{ml}^{11}$.

\section{Uji Stabilitas Sediaan}

Uji stabilitas sediaan digunakan dengan metode cycling test. Sediaan hair tonic disimpan pada suhu $\pm 4^{\circ} \mathrm{C}$ selama 24 jam lalu dikeluarkan dan ditempatkan pada suhu $\pm 40^{\circ} \mathrm{C}$ selama 24 jam, perlakuan ini terhitung satu siklus $^{12}$.

\section{Analisis Data}

Setelah semua data terkumpul tahap selanjutnya adalah menganalisis secara statistik dengan perangkat lunak SPSS menggunakan metode analisis variasi satu arah (ANOVA). Metode ini digunakan untuk melihat adanya kesamaan atau perbedaan rata-rata penurunan 
presentase uji evaluasi metode cycling test pada uji $\mathrm{pH}$, uji bobot jenis dan uji viskositas.

\section{HASIL}

\section{Hasil Determinasi}

Hasil determinasi menunjukan bahwa sampel yang digunakan merupakan tanaman lidah mertua dengan famili Agavaceae dengan spesies Sansevieria trifasciata Prain.

\section{Hasil Pengumpulan dan Penyiapan Simplisia}

Sampel daun lidah mertua segar sebanyak $3 \mathrm{~kg}$, setelah kering lalu dihaluskan dan diperoleh serbuk simplisia sebanyak 525 gram. Serbuk simplisia daun lidah mertua yang digunakan sebanyak 250 gram pada masingmasing metode maserasi dan sokletasi.

\section{Hasil Ekstraksi}

Hasil Rendemen ekstrak etanol daun lidah mertua yang didapat dengan metode maserasi sebanyak 15.048 gram dengan rendemen $6.019 \%$, dan ekstrak kental dengan metode sokletasi sebanyak 19.375 gram dengan rendemen $7.75 \%$. Ekstrak kental dengan metode sokletasi lebih banyak jumlahnya dibandingkan dengan metode maserasi. Prinsip dari metode sokletasi penyarian berkesinambungan, pelarut etanol yang mengekstraksi daun lidah mertua terendam didalam labu alas bulat, kemudian adanya pemanasan untuk menguapkan etanol tanpa ada zat aktif yang ikut menguap dan kemudian mengalami kondensasi menjadi tetesan yang membasahi sampel yang dibungkus dengan kertas saring, sehingga penyarian menjadi lebih efektif bila dibandingkan dengan metode maserasi. Sedangkan kekurangan dari metode maserasi memerlukan waktu yang lama, proses penyariannya tidak sempurna, beberapa senyawa sulit diekstraksi pada suhu kamar ${ }^{13}$.

\section{Uji Stabilitas}

\section{Uji Stabilitas Cycling Test Organoleptik}

Pengujian organoleptik pada sediaan hair tonic ekstrak daun lidah mertua dilakukan setiap siklus, dari hasil uji selama 6 siklus suhu rendah $4^{\circ} \mathrm{C}$ dan suhu tinggi $40^{\circ} \mathrm{C}$ diperoleh hasil bahwa sediaan hair tonic ekstrak lidah mertua secara organoleptik tidak mengalami perubahan warna ataupun bau. Hal ini menunjukan bahwa sediaan hair tonic ekstrak lidah mertua stabil dalam penyimpanan pada suhu $4^{\circ} \mathrm{C}$ dan $40^{\circ} \mathrm{C}$. Data hasil pengujian organoleptik menunjukan hasil yang stabil pada siklus 1 sampai 6 tidak ada perubahan warna, bau dan kejernihan. Hasil organoleptik menunjukan sediaan hair tonic yang stabil pada suhu dingin maupun panas

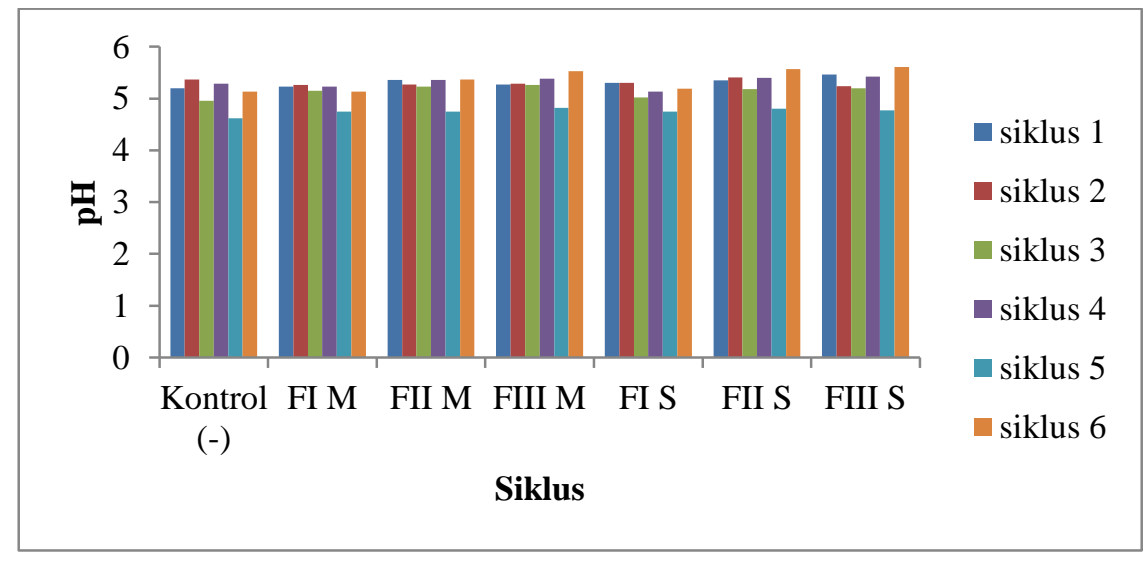

Gambar 1. Hasil Uji Stabilitas Cycling Tes $\mathrm{pH}$ Suhu $4^{\circ} \mathrm{C}$ 


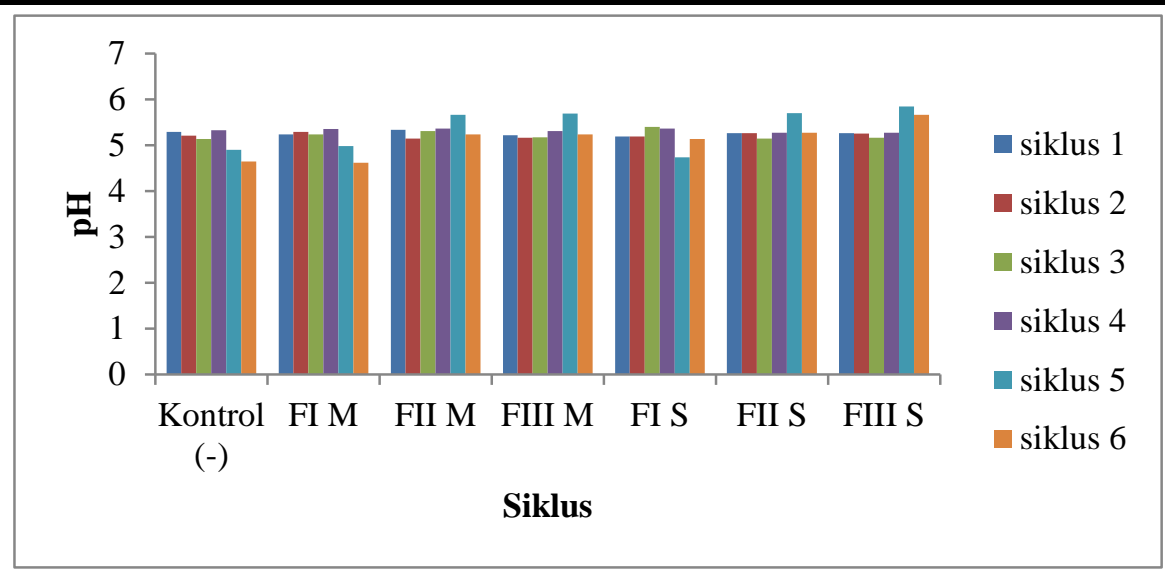

Gambar 2. Hasil Uji Stabilitas Cycling Test $\mathrm{pH}$ Suhu $40^{\circ} \mathrm{C}$

Nilai pH pada suhu $4^{\circ} \mathrm{C}$ dan $40^{\circ} \mathrm{C}$ yang dihasilkan menunjukan adanya penurunan dan peningkatan nilai $\mathrm{pH}$ persiklusnya. Perubahan nilai $\mathrm{pH}$ yang terjadi setelah dilakukan uji stabilitas pada suhu rendah masih termasuk dalam $\mathrm{pH}$ yang tidak mengiritasi kulit yaitu 4,56,5. Selain itu nilai $\mathrm{pH}$ yang dihasilkan masih dalam rentang $\mathrm{pH}$ yang diinginkan. Sehingga masing-masing formulasi memiliki karakteristik nilai $\mathrm{pH}$ yang baik.

Data pengujian $\mathrm{pH}$ yang dihasilkan kemudian diuji statistik dengan menggunakan software SPSS versi 16.0 yaitu dengan uji normalitas (Shapiro-Wilk) dan uji homogenitas (Uji Levene) selanjutnya dilakukan uji
ANOVA. Berdasarkan hasil data statistik uji normalitas (Shapiro-Wilk ) menunjukan nilai signifikan ( $p$-value $>0.05)$ dan uji homogenitas (Levene) menunjukan hasil ( $p$-value $>0.05$ ) maka dapat disimpulkan bahwa data nilai berdistribusi normal dan homogen. Selanjutnya dilakukan analisis variasi satu arah (ANOVA) menunjukan hasil ( $p$-value < 0.05). Hal ini menunjukan bahwa tidak ada perbedaan yang nyata antara rata-rata hitung dari semua perlakuan.

\section{Uji Stabilitas Cycling Test Bobot Jenis}

Hasil pengukuran uji stabilitas cycling test bobot jenis dapat dilihat pada Gambar 3 dan 4.

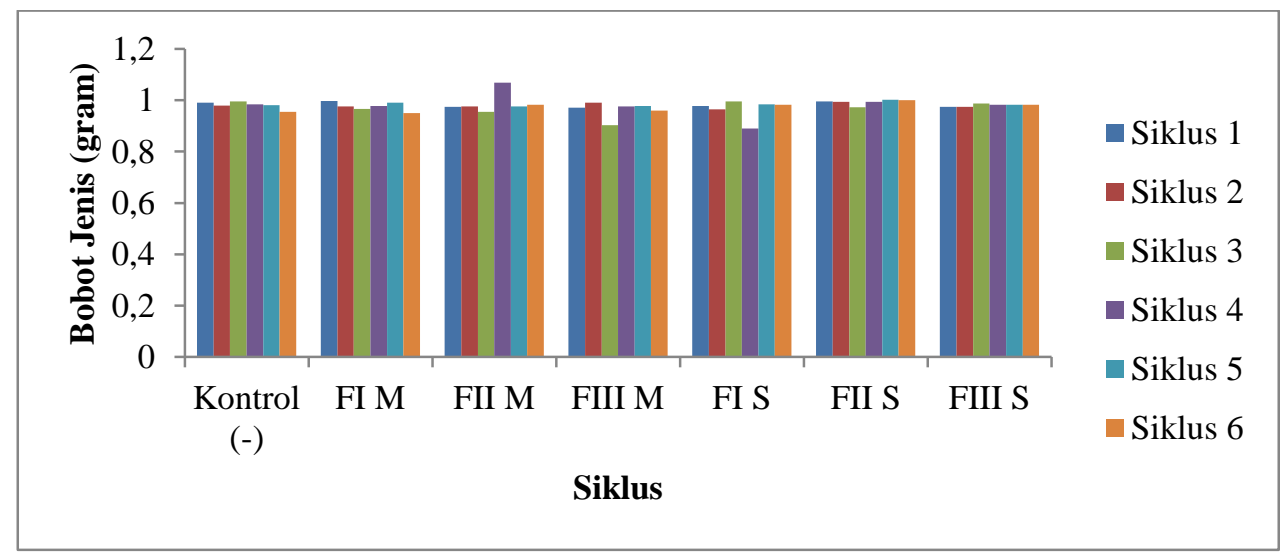

Gambar 3. Hasil Uji Stabilitas Cycling Test Bobot Jenis Suhu $4^{\circ} \mathrm{C}$ 


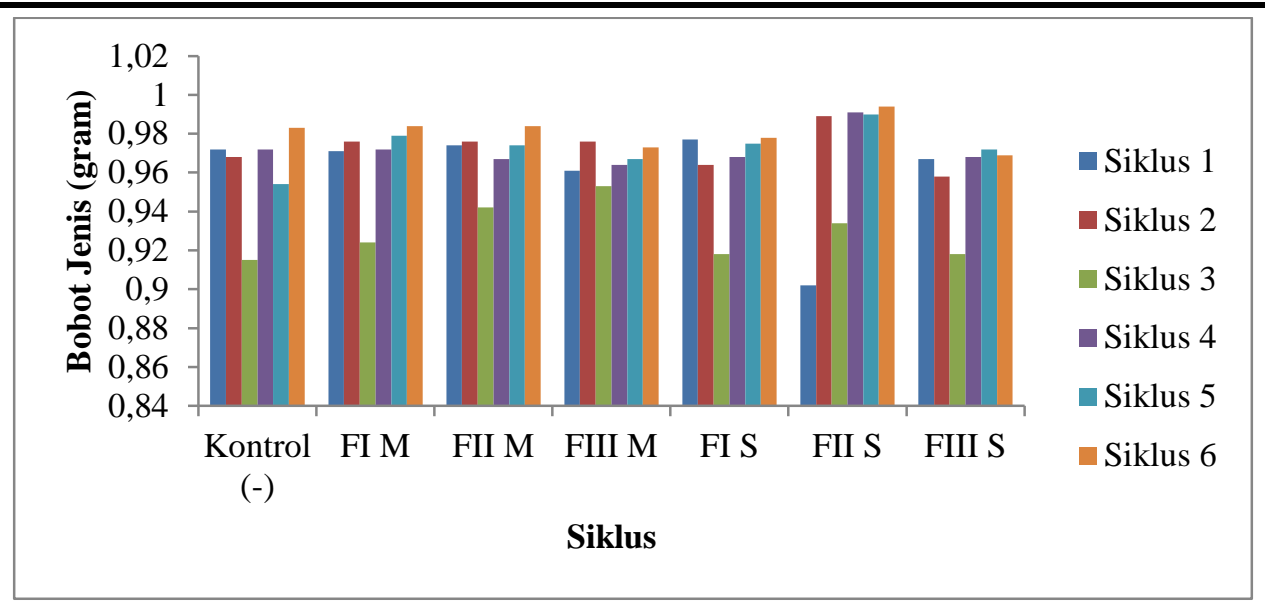

Gambar 4. Hasil Uji Stabilitas Cycling Test Bobot Jenis Suhu $40^{\circ} \mathrm{C}$

Hasil pengukuran bobot jenis selama 6 siklus 12 hari 2 suhu $4^{\circ} \mathrm{C}$ dan $40^{\circ} \mathrm{C}$ pada suhu yang berbeda secara umum mengalami perubahan yang tidak terlalu besar. Hal ini menunjukan bahwa sediaan hair tonic yang dihasilkan memiliki bobot jenis yang relatif stabil pada penyimpanan suhu rendah dan suhu tinggi. Berdasarkan hasil data statistik uji normalitas (Shapiro-Wilk ) menunjukan nilai signifikan ( $p$-value $>0.05)$ dan uji homogenitas (Levene) menunjukan hasil ( $p$-value $>0.05$ ) maka dapat disimpulkan bahwa data nilai berdistribusi normal dan homogen. Selanjutnya dilakukan analisis variasi satu arah (ANOVA) menunjukan hasil ( $p$-value $<0.05$ ). Hal ini menunjukan bahwa tidak ada perbedaan yang nyata antara rata-rata hitung dari semua perlakuan.

\section{Uji Stabilitas Cycling Test Viskositas Suhu $4^{\circ} \mathrm{C}$ dan $40^{\circ} \mathrm{C}$}

Hasil pengukuran $\mathrm{pH}$ uji stabilitas cycling test dapat dilihat pada Gambar 5 dan 6.

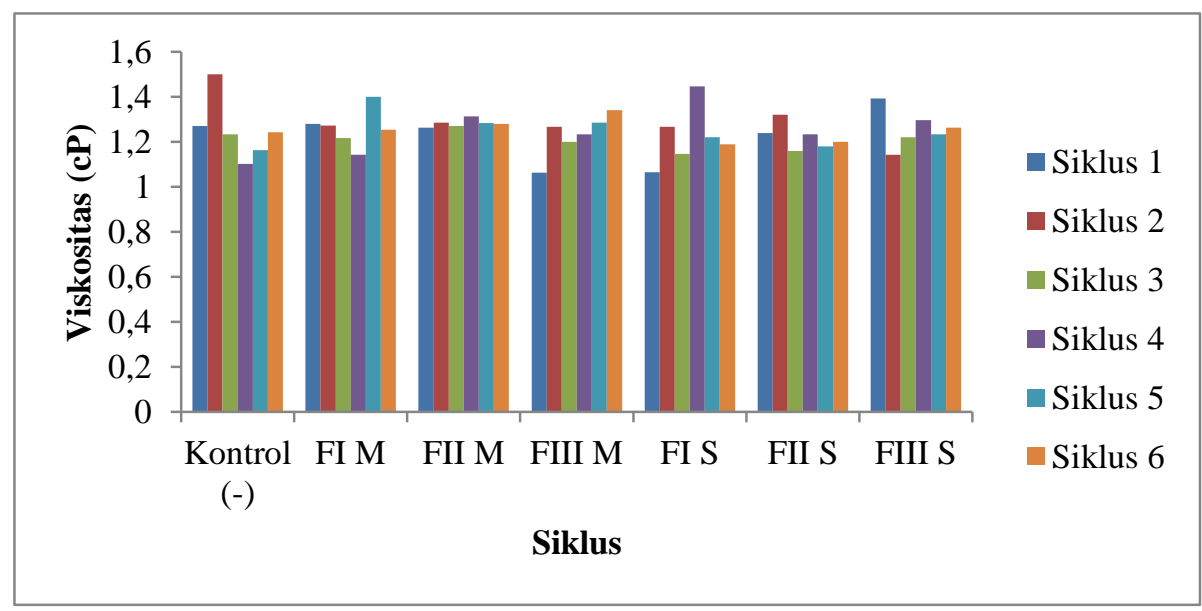

Gambar 5. Hasil Uji Stabilitas Cycling Test Viskositas Suhu $4^{\circ} \mathrm{C}$ 


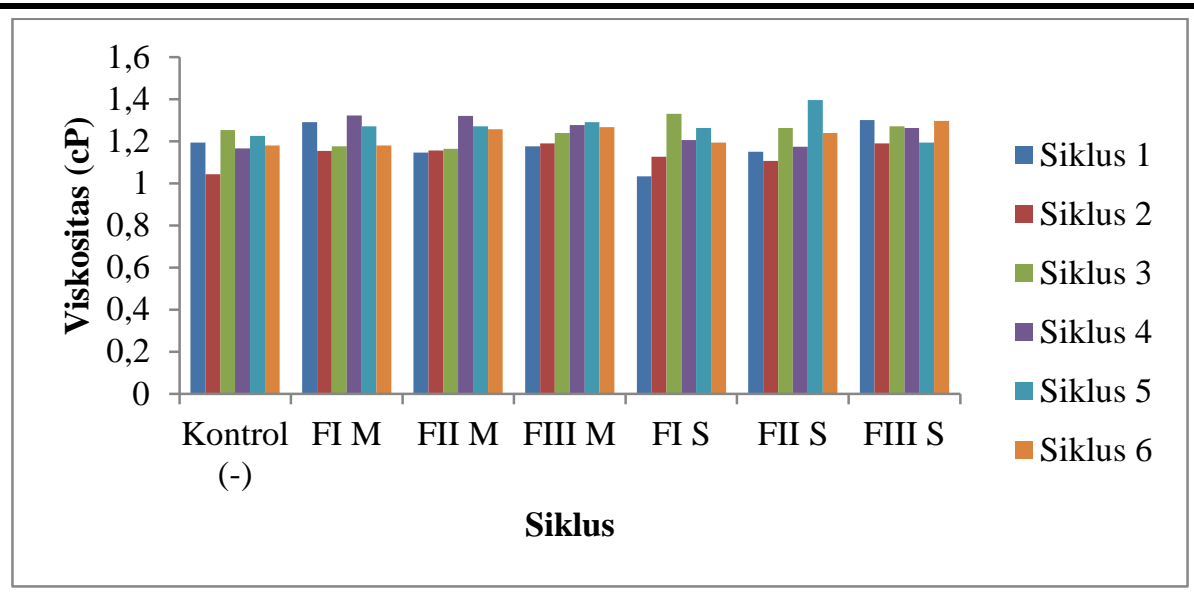

Gambar 6. Hasil Uji Stabilitas Cycling Test Viskositas Suhu $40^{\circ} \mathrm{C}$

Berdasarkan data yang didapat pada pengujian viskositas suhu $4^{\circ} \mathrm{C}$ dan $40^{\circ} \mathrm{C}$ nilai viskositas pada sediaan hair tonic ekstrak lidah mertua setelah dilakukan cycling test mengalami penurunan dan peningkatan nilai viskositas dikarenakan adanya penguapan pelarut pada saat penyimpanan. Viskositas sedian hair tonic yang meningkat pada saat cycling test disebabkan bahan tambahan dari hair tonic yang meningkat kelembabannya dalam sediaan akibat pemanasan yang terjdi selama masa pengujian dan penyimpanan pada suhu rendah sehingga meningkatkan nilai viskositasnya $^{14}$. Perubahan nilai viskositas yang terjadi setelah dilakukan uji stabilitas pada suhu rendah dan tinggi masih dalam rentang nilai viskositas sediaan hair tonic yang baik untuk digunakan pada kulit kepala ban sesuai dengan ketentuan Badan Standarisasi Nasional (1998) no. SNI 16-4955-1998 yaitu dibawah 5 $\mathrm{cP}^{15}$.

Untuk mengetahui adanya perbedaan nilai viskositas uji stabilitas cycling test dilakukan uji analisis statistik. Analisis statistik yang digunakan yaitu dengan uji normalitas (Shapiro-Wilk) dan uji homogenitas (Uji Levene) selanjutnya dilakukan uji ANOVA. Berdasarkan hasil data statistik uji normalitas (Shapiro-Wilk) menunjukan nilai signifikan ( $p$ value > 0.05) dan uji homogenitas (Levene) menunjukan hasil ( $p$-value $>0.05$ ) maka dapat disimpulkan bahwa data nilai berdistribusi normal dan homogen. Selanjutnya dilakukananalisis variasi satu arah (ANOVA) menunjukan hasil ( $p$-value $<0.05$ ). hal ini menunjukan bahwa tidak ada perbedaan yang nyata antara rata-rata hitung dari semua perlakuan.

\section{KESIMPULAN DAN SARAN}

Ekstrak etanol daun lidah mertua (Sansevieria trifasciata Prain.) dapat diformulasikan sebagai sediaan hair tonic yang sesuai dengan persyaratan evaluasi meliputi, pengujian organoleptik, pengujian $\mathrm{pH}$, pengujian bobot jenis, pengujian viskositas dan uji stabilitas. Hasil uji menunjukan ( $p$ value $<0.05)$ tidak ada pengaruh antara metode maserasi dan sokletasi terhadap stabilitas fisik sediaan hair tonic ekstrak lidah mertua.

Saran penulis dalam penelitin ini adalah diharapkan melakukan pengembangan penelitian terkait senyawa dalam lidah mertua (Sansevieria trifasciata Prain.) yang berperan dalam pertumbuhan rambut dan melakukan penelitian terkait aktivitas pertumbuhan rambut

\section{UCAPAN TERIMAKASIH}

Terima kasih yang sebesar-besarnya penulis sampaikan kepada Kemendikbud yang telah mendanai penelitian ini dan semua pihak yang terlibat selama penelitian ini sehingga penelitian ini berjalan lancar. 


\section{DAFTAR PUSTAKA}

1. Nurnanah, Krisnawati M. Pengaruh Hair Tonic Lidah Mertua (Sansevieria Trifasciata Prain) dan Seledri (Apium Graveolens Linn)" Untuk Mengurangi Rambut Rontok. J Beauty Beauty Heal Educ. 2014;3(1):1-8.

2. Aini Q. Uji Aktivitas Pertumbuhan Rambut Kelinci Jantan Dari Sediaan Hair Tonic Yang Mengandung Ekstrak Etanol Daun Mangkokan (Nothopanax scutellarium L.). $J$ Farm Lampung. 2017;6(2).

3. Hidayah, Nurul R, Gozali D, Hendriani R, Mustarichie R. Formulasi dan evaluasi sediaan herbal hair tonic sebagai perangsang pertumbuhan rambut. Maj Farmasetika. 2020;5(5):218-232.

4. Jumadi J. Penggunaan Ekstrak Daun Lidah Mertua (Sansevieria trifasciata P.) Sebagai Ovisida Keong Mas (Pomacea canaliculata L). Published online 2018.

5. Arief H. Tumbuhan Obat Dan Khasiatnya. Penebar Swadaya Grup; 2013.

6. Treml J, Šmejkal K. Flavonoids as Potent Scavengers of Hydroxyl Radicals. Compr Rev Food Sci Food Saf. 2016;15(4):720738. doi:10.1111/1541-4337.12204

7. Rusdiana I. Pengaruh Proporsi Ekstrak Lidah Buaya (Aloe Vera) dan Madu Sebagai Bahan Aktif Hair tonic. e-journal. 2018;7(2):113-120.

8. Istiqomah. Perbandingan Metode Ekstraksi Maserasi Dan Sokletasi Terhadap Kadar Piperin Buah Cabe Jawa (Piperis Retrofracti Fructus). Published online 2013.
9. Ditjen POM. Parameter Standar Umum Ekstrak Tumbuhan Obat. Departemen Kesehatan Republik Indonesia; 2000.

10. Rivai H, Putra RY, Krisyanella. Penentuan Pengaruh Jenis Pelarut Pengekstrak Terhadap Perolehan Kadar Senyawa Fenolat Dan Aktifitas Antioksidan Dari Daun Jambu Biji (Psidium guajava L.). $J$ Farm Higea. 2012;4(1):16-23.

11. Agustin SG, Purba AV, W AE. Pengembangan Hair Tonik Kombinasi Ekstrak Etanol Daun Pandan Wangi Dan Daun lidah Mertua. Media Inf. 2018;14(1):63-68.

12. Aryani NLD, Parfati N, Feby P. Stabilitas Fisik dan Kimia Sediaan Gel dan Penyubur Rambut Dari Ekstrak Etanol Biji Anggur (Vitis Vinfare L). In: Prosiding Seminar Ilmiah XIX Dan Rapat Kerja Nasional Ikatan Apoteker Indonesia 2011. Pt. ISFI Penerbitan; 2012.

13. Harborne J. Metode Fitokimia Penuntun Dan Cara Modern Menganalisa Tumbuhan. 3rd ed. ITB; 1987.

14. D.K S, S.S K. Handbook of Vegetable Science and Technology: Production, Compostion, Storange, and Processing. CRC Press; 1998.

15. Jubaidah S, Indriyani R. Formulasi Dan Uji Pertumbuhan Rambut Kelinci Dari Sediaan Hair Tonic Kombinasi Ekstrak Daun Saledri (Apium Graveolens Linn) Dan Daun Mangkolan (Polyscias Scutellaria (Burm.f.) Fosberg). 